\title{
Groin Lymph Node Metastases in Pedal Melanoma in Nigeria
}

\author{
Wilson IB Onuigbo* \\ Department of Pathology, Medical Foundation and Clinic, Nigeria
}

Submission: December 08, 2017; Published: January 03, 2018

"Correspondence Address: Wilson IB Onuigbo, Department of Pathology, Medical Foundation and Clinic, 8 Nsukka Lane, Enugu Nigeria, Email: wilson.onuigbo@gmail.com

\section{Abstract}

Surgical therapy remains the primary and most effective intervention for the groin regional lymph node basin in melanoma. Accordingly, this study sought to present its parameters from a developing community. Of the 34 cases reviewed, the male/female ratio was equal, the 51-60 years age group preponderated as did left sided lesions. Moreover, the excised lesions varied from 2 to $13 \mathrm{~cm}$ (mean $7 \mathrm{~cm}$ ). Whereas 25 patients were operated on at Enugu, the capital city of the Region, up to 9 other towns were involved, thereby indicating that a central laboratory benefits distant hospitals unlike the UK, debate on the issue..

Keywords: Melanoma; Foot; Groin; Metastases; Management; Developing community

\section{Introduction}

Concerning the management of regional lymph node basin in melanoma, Love \& Delman [1] were convinced that "Surgical therapy remains the primary and most effective intervention for the disease." Consequently, this concept is verified in a developing community in Nigeria. In particular, the Ethnic Group involved is the Igbos [2]. Moreover, on the basis of a Birmingham (UK) affirmation that the establishment of a histopathology data pool facilitates epidemiological analysis [3], this study depends on such a pool existing in the capital city, Enugu, in the then Eastern Region of Nigeria, the author being the pioneer pathologist. The biopsy service was encouraged by my insistence on reasonably well filled Request forms. In particular, the author kept a copy personally, thus ensuring manual data recovery and tabulation.

\section{Investigation}

Table 1: Age and sex distribution pattern.

\begin{tabular}{|c|c|c|c|}
\hline Age group & M & F & Total \\
\hline$<30$ & 0 & 1 & 1 \\
\hline $31-40$ & 0 & 5 & 5 \\
\hline $41-50$ & 4 & 2 & 6 \\
\hline $51-60$ & 10 & 5 & 15 \\
\hline $61-70$ & 2 & 4 & 6 \\
\hline $71+$ & 1 & 0 & 1 \\
\hline Total & 17 & 17 & 34 \\
\hline
\end{tabular}

Table 1 Apparently, the 51- 60 age group stood out. Of the other relevant particulars,

i. The left foot was involved 22 times as against the 12 on the right;

ii. Of the towns involved, the Capital City took primary place in 25 instances, while the remaining 9 cases were shared by other towns; and

iii. The removed masses varied in sizes from $2 \mathrm{~cm}$ to $13 \mathrm{~cm}$ (mean $7 \mathrm{~cm}$ ).

\section{Discussion}

Years ago, there was a debate, in UK as to whether distant hospitals could benefit from a central laboratory [4]. This has been punctured with local results [5]. Considering what is missing here, the following may be highlighted thus:

a. Theoptimum timing on extent of regional lymphadenectomy [6],

b. Defining of patients eligible for only a superficial groin dissection or a combined superficial and deep groin dissection [7],

c. Evaluating the association between the number of excised regional lymph nodes, and melanoma-specific survival [8],

d. Whether aggressive surgical therapy of regional lymph 
node metastases is warranted [9], and

e. Whether immediate complete lymph node dissection after a positive sentinel lymph node biopsy is associated with fewer initial nodal basin recurrences but similar melanomaspecific survival [10]. Of course, in conclusion, the above are a far cry from the present mundane but documentable data!

\section{References}

1. Jaffe HL (1958) Tumors and timorous conditions of the bones and joints. Lea \& Febiger, Philadelphia, USA, pp. 150.

2. Macartney JC, Rollaston TP, Codling BW (1980) Use of a histopathology data pool for epidemiological analysis. J Clin Pathol 33(4): 351-353.
3. Basden GT (1966) Niger Ibos. Cass, London, UK.

4. Karr MA, Aulicino PL, Dupuy TE, Gwathmey FW (1984) Osteochondromas of the hand in hereditary multiple exostosis: Report of a case presenting as a blocked proximal interphalangeal joint. J Hand Surg 9(2): 264-268.

5. Mazabraud A (2008) Osteogenic Exostosis (Osteochondroma), Multiple Exotoses, Subungual Exostosis, Metachondromatosis. Pathology of Bone Tumours, Heidelberg: Springer-Verlag Berlin H p. 63-75.

6. Bovee JV (2008) Multiple osteochondromas. Orphan J Rare Dis 3:3.

7. Shtomakher G, Kaufman MA, Bhoola PH, Patel AA, Rice SM, et al. (2015) Multiple osteocartilaginious exostoses of the lower extremity: A case report. Foot 25(1): 62-65. 